International Journal of Life Sciences
Available online at http://sciencescholar.us/journal/index.php/ijls
Vol. 3 No. 3, December 2019, pages: $41 \sim 52$
e-ISSN: $2550-6986$, p-ISSN: $2550-6994$
https://doi.org/10.29332/ijls.v3n3.370

\title{
The Consumer Perception On Balinese Local Culture-Based Packaging Design on white Oyster Mushroom Chips (Pleorotus Ostreatus)
}

\author{
A. A. Sri Mahyuni a , I Nyoman Sucipta b ${ }^{b}$ I Made Adnyana c, Made Sudiana Mahendra d \\ Article history: Received 27 May 2019, Accepted: 31 August 2019, Published: 03 December 2019
}

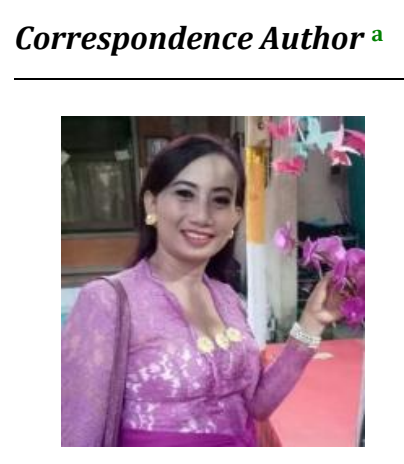

Keywords

Bali local culture; consumer perception; mushroom chips; packaging design; white oyster;

\begin{abstract}
Food products competition of Micro, Small and Medium Enterprises (MSMEs) is due to the products of local businesses and imported products, both legal and illegal from China, Malaysia, Singapore, Thailand, and Japan. This is because most of the products of Micro, Small and Medium Enterprises (MSMEs) are less attractive, innovative and creative packaging. Food products are only wrapped in transparent plastic without any label or information, thus giving the impression of being less attractive. This makes Indonesian Micro, Small and Medium Enterprises (MSME) products less competitive compared to manufactured products and products from abroad. The packaging is one of the important marketing tools, not just as a wrapper. The packaging is a process related to the design and manufacture of containers or wrappers for a product. Packaging must be designed with a suitable shape and size and graphic design must be able to attract buyers. One of the graphic design elements as an attractive design of white oyster mushroom chips (Pleorotus Ostreatus) packaging as a souvenir is the use of Balinese local cultural markers in packaging design. Theories used in this study are the theory of semiotics and visual communication design theory in particular about product packaging. The method used is a descriptive qualitative method. The data collection method uses the method of observation, interviews, literature, and documentation. It can be concluded from the study that the local cultural markers on the main display panel as an eye-catcher that is used as an illustration on the packaging design of white oyster mushroom chips (Pleorotus Ostreatus) are very diverse such as the use of Balinese black and white checkered motif or poleng anyar, patra punggel illustrations, and illustrations of Payas / Balinese fashion styles, each of which has a philosophical meaning and is always used in various Hindu ceremonies in Bali. Statistical analysis shows that the effect of packaging design on consumer perception is assessed positively and significantly.
\end{abstract}

a Udayana University, Denpasar, Indonesia

b Udayana University, Denpasar, Indonesia

c Udayana University, Denpasar, Indonesia

d Udayana University, Denpasar, Indonesia 
e-ISSN: 2550-6986, p-ISSN: 2550-6994@C Copyright 2019. The Author. SS Journals Published by Universidad Técnica de Manabí.

This is an open-access article under the CC BY-SA 4.0 license

(https://creativecommons.org/licenses/by-sa/4.0/)

All rights reserved.

\section{Contents}

Abstract

1. Introduction

2. Materials and Methods

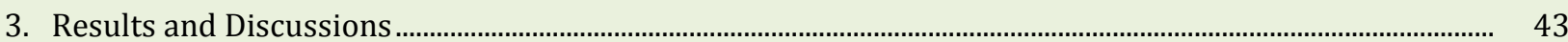

3.1 The meaning of packaging on white oyster mushroom (Pleorotus ostreatus) chips ................................ $\quad 43$

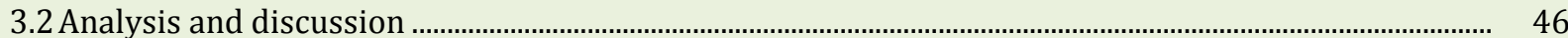

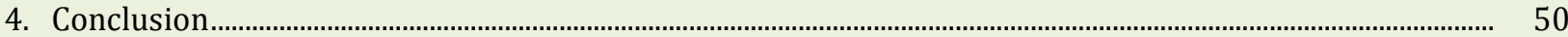

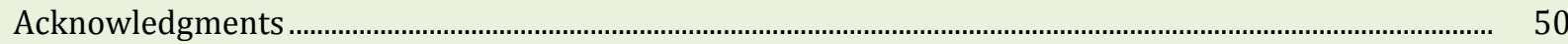

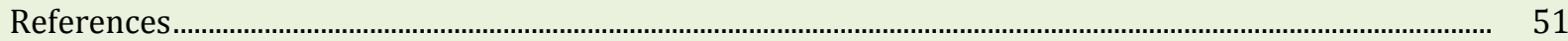

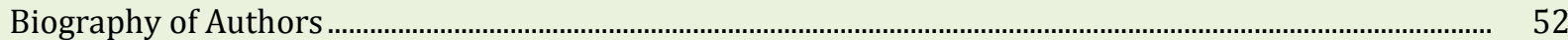

\section{Introduction}

Bali as a tourist destination is known to have natural beauty with distinctive panoramas, cultural diversity and the most amazing thing is the friendliness of its people who always greet visitors with a friendly atmosphere. The social life of Balinese people who are religious with religious activities that are always associated with artistic activities has made Bali an area that has a unique culture that encourages the establishment of Micro and Medium Enterprises (UMKM) in the culinary sector as a support for tourism activities which are very important to meet the food needs of tourists and simply as souvenirs typical of an area. White oyster mushroom chips are one of the souvenir products that are now being developed in Bali.

White oyster mushroom chips are one of the processed oyster mushrooms which is very popular with most people both from children, adolescents, adults and even parents in the form of fresh food and packaged products. White oyster mushroom chips that are only packaged modestly are certainly not suitable to be used as commodities in the typical Balinese souvenir market.

Food products competition of Micro, Small and Medium Enterprises (MSMEs) is due to the products of local businesses and imported products, both legal and illegal from China, Malaysia, Singapore, Thailand, and Japan. This is because most of the products of Micro, Small and Medium Enterprises (MSMEs) are less attractive, innovative and creative packaging. Food products are only wrapped in transparent plastic without any label or information, thus giving the impression of being less attractive (Ministry of Cooperatives and SMEs, 2016). This makes Indonesian Micro, Small and Medium Enterprises (MSME) products less competitive compared to manufactured products and products from abroad. The packaging is a process related to the design and manufacture of containers or wrappers for a product (Tjiptono, 2007; Ariani et al., 2018). Packaging must be designed with a suitable shape and size and graphic design must be able to attract buyers. One of the graphic design elements as an attractive design of white oyster mushroom chips (Pleorotus Ostreatus) packaging as a souvenir is the use of Balinese local cultural markers in packaging design.

At present, the issue of packaging design and packaging is a very important global industry. The importance of packaging can be seen from the fact that it is almost impossible to find products sold in the market without packaging. Packaging techniques, packaging design, and selection of appropriate packaging materials require a lot of considerations but still aim at the main goal that the packaging must provide optimal protective properties. Damage to the product is caused by light, oxygen, humidity, microbes or insects that affect the quality, nutritional value and shelf life. Packaging must be designed with a suitable shape and size and graphic design must be able to attract buyers. Packaging is not only required to fulfill basic functions as a container, protection and preservation, communication media, and ease of use, but packaging is also required to be environmentally friendly and active in providing product protection (active packaging) as well as intelligent packaging in providing information on the product (Sucipta \& Suriasih, 2016; Suryasa, 2019). 
According to Klimchuk \& Krasovec (2007), in designing packaging, the basic principles of design are adjusted to meet the objectives of each design task. There are many variables that influence how and why packaging design can attract consumers from a pure design perspective (transferring other marketing variables such as price, location, and brand loyalty) there are important elements that capture consumers' attention very well and break through the attention of the visual crowd in the competitive retail. The four main focal points are color, physical structure, and shape, symbols and numbers and typography. Packaging design that can serve the intended target market must be in accordance with the local culture, appropriate and accurate language order, visually logical and competitively designed.

The White Oyster Mushroom (Pleorotus Ostreatus) Chips Company, which is being developed in Bali, is currently considering design aspects because its main purpose is to be a souvenir, so the businessmen pack their products using local Balinese cultural signs. A sign is something that for someone means something else (Zoest, 1993; Suarta, 2017), meanwhile the local culture in question is the local values of the results of community cultivation in an area that is naturally formed and obtained through the process of learning from time to time, one of them in the form of art and tradition. Signs of local culture that are used as illustrations in the design of white oyster mushroom chips packaging include; the use of poleng or black and white checkered motifs and patra punggel on each package, the use of Balinese ornaments, Barong Ket illustrations, meru tumpeng solas or eleven-storey Balinese temple roof illustrations, and Payas Bali or Balinese makeup illustrations. In Bali, the signs of the local culture certainly have their own meanings that are both sacred and profane and have their own meaning and philosophy. The research question is: what exactly the meaning of each local cultural identity that is applied to the packaging design of white oyster (Pleorotus Ostreatus) mushroom chips? This study aims to determine the meaning contained in each local cultural identity that is applied to the packaging design of white oyster mushroom (Pleorotus Ostreatus) chips.

\section{Materials and Methods}

This research was conducted at the Denpasar Design Center, Jalan Melati number 31 Denpasar Bali using a descriptive qualitative method that will explain the meaning of local cultural identity on the packaging design of white oyster mushroom chips (Pleorotus Ostreatus) as the appeal of packaging and the application of the basic principles of art and design to visual design elements that add aesthetic value to the product. Data analysis in this study uses a semiotic and aesthetic approach.

The material used in this study is white Art Paper with a thickness of 250 grams. The tools used in this study are computer or laptop, CorelDRAW X7 software, printer, scissors, ruler, cutter, double-sided tape, and glue. Data inventorying in this study is in the form of primary data and secondary data. Secondary data consists of data on the number of MSMEs in Bali Province and Central Agency of Statistics or BPS data of 2017. Primary data were obtained from the process of making packaging designs, observing and recording local cultural signs used as illustrations in the design of mushroom chip packaging white oysters, among others; the use of poleng anyar motifs and patra punggel on each packaging, the use of Balinese ornaments, and Balinese Payas illustrations and other supporting data that are filled out on the questionnaire form. The design data were then made into CorelDRAW X7 Software. The process has produced the packaging design of white oyster mushroom (Pleorotus ostreatus) chips. There is three data analysis in this study i.e. by using semiotic, aesthetic and quantitative approach.

\section{Results and Discussions}

\subsection{The meaning of packaging on white oyster mushroom (Pleorotus ostreatus) chips}

On each packet of white oyster mushroom (Pleorotus ostreatus) chips displaying local cultural elements as its appeal, it is seen on the middle side of the package using poleng motifs. Each of the local cultures displayed on this package has a sacred meaning for Hindus, especially in Bali, as an example of the use of poleng motifs or saput poleng or black and white checkered clothes. Poleng is a checkered motif with a combination of black

Mahyuni, A. A. S., Sucipta, I. N., Adnyana, I. M., \& Mahendra, M. S. (2019). The consumer perception on balinese local culture-based packaging design on white oyster mushroom chips (Pleorotus ostreatus). International Journal of Life Sciences, 3(3), 41-52. https://doi.org/10.29332/ijls.v3n3.370 
and white colors, sometimes between the two colors interspersed with red (Rupawan, 2008; Korry et al., 2017; Jaminyasa et al., 2017).

In Bali the use of saput poleng is always associated with religious ceremonial activities, especially Hinduism, such as saput poleng that is wrapped around certain trees (large banyan trees, pule trees), and on statues that function as guards for example statues on bridges, on doors gates, at crossroads and others, wrappers in sesabukan (magical belt used to gain bodily strength), wrapped around the kulkul (wooden drum), wrapped around arub (weapons such as sickles stored in temples), and ceremonial spears. In addition, saput poleng is also wrapped around Pelinggih Ratu Ngerurah and Tunggun Karang. Besides being placed in the sacred places, saput poleng are also worn by pecalang (traditional village security guards), balian usadha (traditional healers) and Jero Dalang (puppeteers) in their capacity as penguwat (purification).

According to Rupawan (2008), saput poleng is divided into 3 types based on their color: (1). Poleng rwabhninedha, which is a white and black poleng motif and has a philosophical meaning that shows the values of rwabhinedha namely the concept of difference created by Ida Sang Hyang Widhi Wasa, the Almighty God to create harmony and balance of the universe, (2). Poleng sudhamala, which are white, gray and black poleng motifs. This color is a reflection of rwabhinedha accompanied by intermediaries as harmonizers in rwabhinedha. The gray color is as a mediator of good and bad traits in rwabhinedha. (3). Poleng Tridatu, which is a white, black and red poleng motif. White is identical to consciousness or wisdom, red is energy or motion, and black symbolizes inhibitors. When associated with Tri Murti, the red color is the symbol of Brahma as the creator, the black color of Lord Vishnu as the preserver, and the white color of Lord Shiva as the destroyer. These three gods are associated with life, namely; born, lived and died.

In addition to using the poleng rwabhinedha motif, some packaging designs of white oyster mushroom (Pleorotus Ostreatus) chips also use patterns not like poleng motifs in general, but use a variety of colors, such as the gradation of yellow and light green colors called the poleng anyar motif or new poleng motifs that appear later and are permeating the functions of the three poleng colors that precede it (Rupawan, 2008). Poleng Anyar motif is a motif that uses the same patterns as the previous poleng motif, but uses a variety of color combinations. The presence of new poleng anyar motifs because the poleng motif itself has become a local Balinese cultural identity so that it is not only used on sacred ceremonies but also profane in nature, both as decoration on the interior and exterior of hotels, restaurants and as visual elements of products visual communication design to meet the needs of tourism activities.

Newer poleng motifs based on color are divided into 12 (twelve) types, namely: (1). Newer poleng motif in blue, light blue and white, (2). Newer poleng motif in blue, black and white, (3). Newer poleng motif in red, pink and white, (4). Newer poleng motif in red, pink and black, (5). Newer poleng motif with green, light green and white color, (6). Newer poleng motif in green, light green and black, (7). Newer poleng motif in yellow, light yellow and black, (8). Newer poleng motif in yellow, light yellow and white, (9). Newer poleng motif in purple, light purple and black, (10). Newer poleng motif in purple, light purple and white, (11). Newer poleng motif with orange, light orange and black, and (12). Newer poleng motif with orange, light orange, and white.

In addition to the illustration of poleng motifs, local cultural signs displayed on the packaging of white oyster mushroom chips are the use of patra punggel which has been sterilized into simpler forms. This patra punggel is displayed by combining it face to face. Patra punggel is a type of patra that has an identity as an authentic Balinese patra. This assumption is based on the names of the elements of the motifs that make it up, namely the combination of animal and plant stilization that lives and grows in Bali. These elements include jackfruit pulp, batun poh (mango seed), kepitan ( the petals on jackfruit), util (top of a circular fern stem), jangar siyap (rooster's comb) and ears of suckling pig.

The basic color of all white oyster mushroom chip packs (Pleorotus Ostreatus) uses a light green base color that tends to turn yellow, which has a fresh, light, pleasant, and natural meaning. The label contains the product name, logo and trademark, type of product, product net weight, licensing (P-IRT), product description, expiration date, barcode, composition, nutritional facts, address and manufacturer's description.

On the packaging of chips of the private label using traditional Balinese payas as an element of local culture. The basic concept of traditional Balinese clothing is the Tri Angga concept which consists of: (1). Dewa angga, i.e. clothing that is used from the neck to the head can be a udeng / headband and pepusungan, (2). Manusa angga, which is clothing that is used from above the navel to the neck can be in the form of clothes, kebaya, and saput, (3). Butha angga, which is clothing that is used from the navel to the bottom can be cloth/kamen. 
Description:

1. Name

2. Logo

3. Trademark

4. Product Type

5. Net Weight

6. Licensing

7. Product Description

8. Expiry date

9. Barcode

10. Composition

11. Address and Producer's details

12. Barong Ket illustration

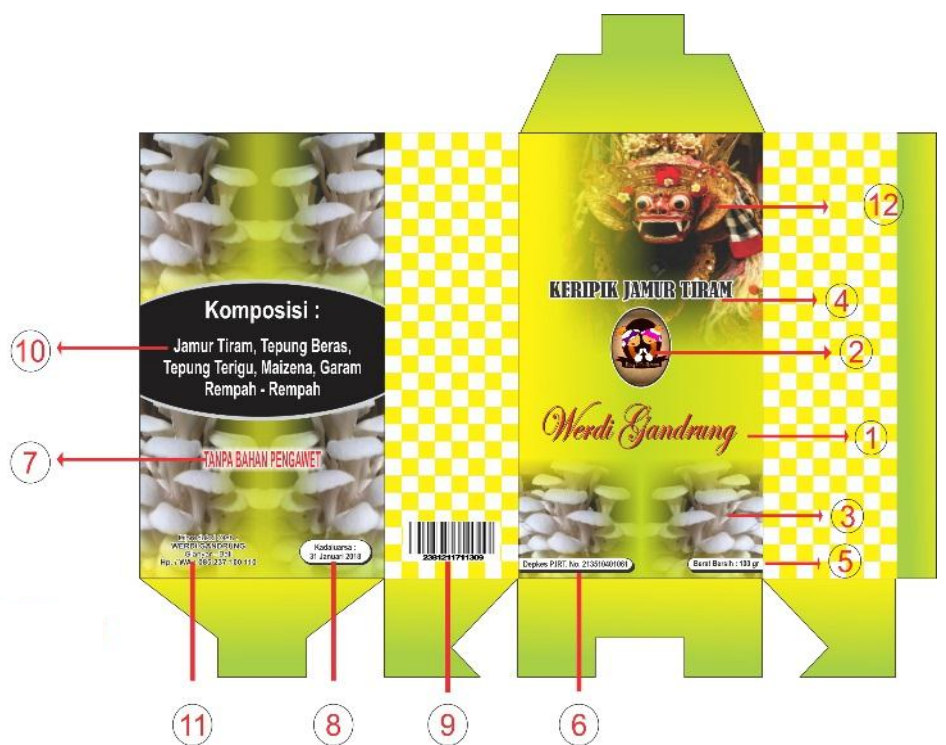

Picture 1. Packaging design with Barong Ket illustration

Description:

1. Name

2. Logo

3. Trademark

4. Product Type

5. Net Weight

6. Licensing

7. Product Description

8. Expiry date

9. Barcode

10. Composition

11 Address and Producer's details

12. Illustration of Meru Tumpang Solas

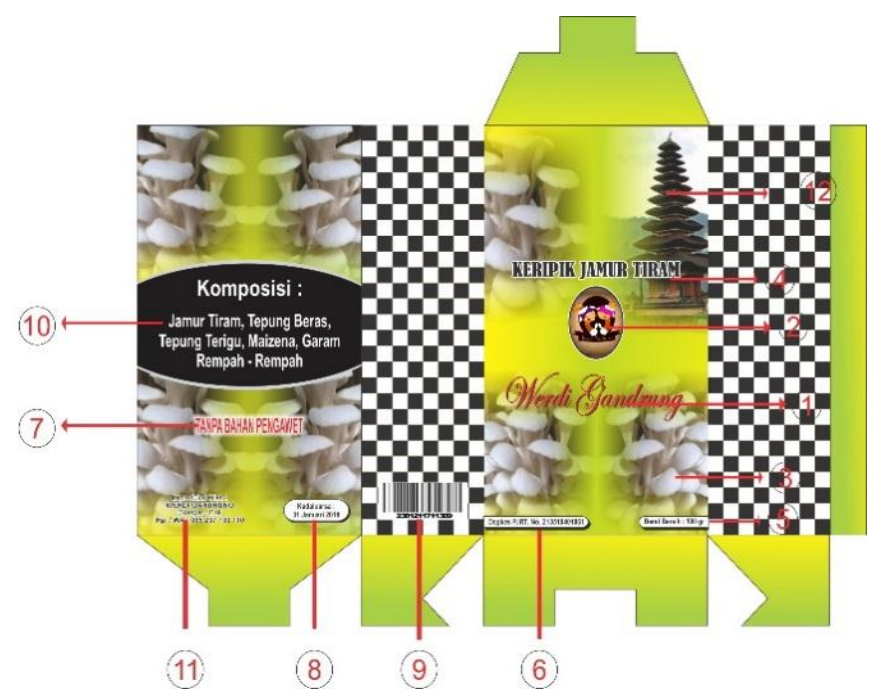

Figure 2. Design packaging with Meru illustration

Mahyuni, A. A. S., Sucipta, I. N., Adnyana, I. M., \& Mahendra, M. S. (2019). The consumer perception on balinese local culture-based packaging design on white oyster mushroom chips (Pleorotus ostreatus). International Journal of Life Sciences, 3(3), 41-52. https://doi.org/10.29332/ijls.v3n3.370 
Description:

1. Name

2. Logo

3. Trademark

4. Product Type

5. Net Weight

6. Licensing

7. Product Description

8. Expiry date

9. Barcode

10. Composition

11 Address and Producer's details

12. Illustration of Balinese Dancers

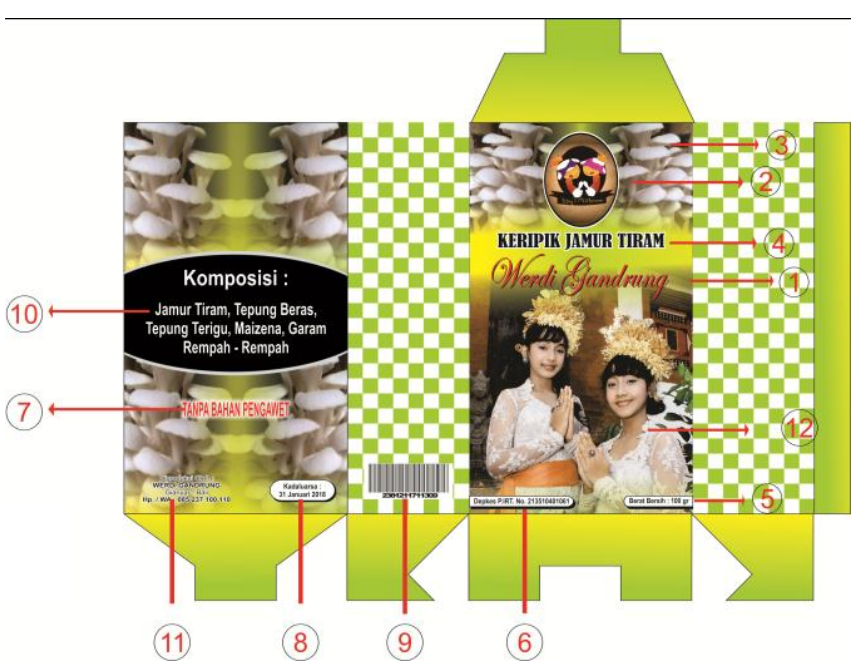

(11)

Figure 3. Packaging design with Payas Bali/ Balinese make-up Illustration

\subsection{Analysis and discussion}

\section{a) Characteristics of respondents}

After the questionnaires were distributed, it was obtained the results of data collection from respondents' answers namely the description of the identity of respondents as many as 180 people. The questionnaire comprises the respondent's profile and questions related to the study which consisted of a name, gender, employment status, and marital status.

Table 1

Characteristics of Respondents

\begin{tabular}{lcc}
\hline Characteristics of Respondents & Number of people & Percentage (\%) \\
\hline Sex & & \\
Male & 55 & 30,6 \\
Female & 125 & 69,4 \\
Age & & \\
30-40 years old & 44 & 24,4 \\
41-50 years old & 91 & 50,6 \\
51-60 years old & 32 & 17,8 \\
>60 years old & 13 & 7,2 \\
Job-status & & \\
Civil Servants & 74 & 41,1 \\
Self-employed & 15 & 8,3 \\
Housewives & 21 & 11,7 \\
Employees & 52 & 28,19 \\
Retired & 4 & 2,2 \\
Others & 14 & 7,3 \\
Marital Status & & \\
Married & 106 & 58,9 \\
Single/Widow/Widower & 74 & 41,1 \\
Total & 180 & 100,00 \\
\hline
\end{tabular}

Based on the table above, male respondents were 55 people $(30.6 \%)$ and female respondents were 125 people (69.4\%), respondents aged 41-50 years old were the most $(50.6 \%)$, while respondents aged $>60$ years old were the fewest (7.2\%), respondents of civil servants were the largest, as many as 74 people (41.4\%) and 
the least were retired respondents as many as 4 people (2.2\%), married respondents were 106 people (58.9\%) and those single/widowed/widower respondents were 74 people (41.1\%).

\section{b) Instrumental test \\ Validity and reliability tests}

These tests were carried out with the aim of measuring the validity or invalidity of a questionnaire item. Corrected item-total correlation or $r$ table must be smaller than $r$ count with a significance level of 5\%. The data is said to be valid if the validity test of $r$ table $<r$ count. In this study, the researchers used $r$ table with a significant level of $5 \%$ and a total of 180 respondents.

The reliability test aims to determine the consistency/conditions of measurement results of an instrument if the instrument is used again as a measurement tool for an object/respondent. One of the reliability testing methods is the Alpha-Cronbach method. If a data score above 0.5, the research is reliable. The following table presents the reliability testing of each variable. The results of the analysis of all Alpha-Cronbach values obtained from each variable are $>0.5$, thus, it can be said that all the values of each variable are reliable.

Table 2

Test results of validity and reliability of research instruments variable quality of the packaging design, packaging design materials, label innovations in packaging design and the consumers' perception

\begin{tabular}{|c|c|c|c|c|c|}
\hline Variables & Statement Items & $\begin{array}{l}\text { Correlation } \\
\text { coefficient }\end{array}$ & Information & $\begin{array}{l}\text { Alpha } \\
\text { Cronbach }\end{array}$ & Description \\
\hline & $\mathrm{X} 1.1$ & 0,889 & Valid & \multirow{6}{*}{0,955} & \multirow{6}{*}{ Reliable } \\
\hline & $\mathrm{X} 1.2$ & 0,903 & Valid & & \\
\hline Quality of Packaging & $\mathrm{X} 1.3$ & 0,877 & Valid & & \\
\hline \multirow[t]{4}{*}{ Design } & $\mathrm{X} 1.4$ & 0,872 & Valid & & \\
\hline & $\mathrm{X} 1.5$ & 0,877 & Valid & & \\
\hline & $\mathrm{X} 1.6$ & 0,746 & Valid & & \\
\hline & X2.1 & 0,773 & Valid & \multirow{4}{*}{0,903} & \multirow{4}{*}{ Reliable } \\
\hline Packaging Material & $\mathrm{X} 2.2$ & 0,690 & Valid & & \\
\hline \multirow[t]{5}{*}{ Design } & $\mathrm{X} 2.3$ & 0,841 & Valid & & \\
\hline & X2.4 & 0,843 & Valid & & \\
\hline & X3.1 & 0,733 & Valid & \multirow{8}{*}{0,905} & \multirow{8}{*}{ Reliable } \\
\hline & X3.2 & 0,686 & Valid & & \\
\hline & X3.3 & 0,451 & Valid & & \\
\hline Label Innovations in & X3.4 & 0,578 & Valid & & \\
\hline \multirow[t]{4}{*}{ Packaging Design } & X3.5 & 0,177 & Valid & & \\
\hline & X3.6 & 0,764 & Valid & & \\
\hline & X3.7 & 0,811 & Valid & & \\
\hline & X3.8 & 0,786 & Valid & & \\
\hline \multirow{4}{*}{ Consumer Perception } & $\mathrm{Y} 1$ & 0,759 & Valid & \multirow{4}{*}{0,876} & \multirow{4}{*}{ Reliable } \\
\hline & Y2 & 0,732 & Valid & & \\
\hline & Y3 & 0,781 & Valid & & \\
\hline & Y4 & 0,672 & Valid & & \\
\hline
\end{tabular}

\section{c) Hypothesis testing}

This hypothesis test is used to test the truth of the hypothesis, which states that the quality of packaging design, packaging design materials, and packaging label innovation are assumed to have a significant effect on consumer perception.

1) Coefficient of determination $\left(R^{2}\right)$

The coefficient of determination measures how far the model's ability to explain the variation of the dependent variable. The value of the coefficient of determination is 0 (zero) and 1 (one). A small $\mathrm{R}$

Mahyuni, A. A. S., Sucipta, I. N., Adnyana, I. M., \& Mahendra, M. S. (2019). The consumer perception on balinese local culture-based packaging design on white oyster mushroom chips (Pleorotus ostreatus). International Journal of Life Sciences, 3(3), 41-52. https://doi.org/10.29332/ijls.v3n3.370 
square value means that the ability of independent variables to explain the dependent variables is very limited. A value close to one means that the independent variables provide almost all the information needed to predict the dependent variable.

Table 3

Determination of coefficient test

\begin{tabular}{llll}
\hline Model & $\mathrm{R}$ & R Square & Standard of Error \\
\hline 1 & 0.769 & 0.592 & 2.213 \\
\hline
\end{tabular}

Description:

- $\quad$ R square figures (correlation numbers and squared $r$ ) of 0.592 . R square number is also called the coefficient of determination the magnitude of the coefficient of determination is 0.592 or equivalent to $59.2 \%$. This figure shows the influence of the quality of packaging design, packaging design materials and packaging label innovation together on consumer perceptions, while the remaining $40.8 \%(100 \%-59.2 \%)$ can be explained by other causative factors.

- The magnitude of the Standard Error of the Estimate (SEE) is 2.213 (for consumer perception variables). When compared with the standard deviation (STD) of 3.435, the SEE number is smaller. This means that the SEE number is a good predictor of a dependent variable which must be smaller than the standard deviation number (SEE <STD).

\section{2) F test}

The statistical F test basically shows whether all the independent variables intended in the model have a joint effect on the related / dependent variable. Decision-making based on probability is:

a. If the probability is $>0.05$ then Ho is accepted and Ha is rejected

b. If the probability is $<0.05$ then Ho is rejected and Ha is accepted.

Table 4

Anova

\begin{tabular}{lllllll}
\hline \multirow{2}{*}{ Model } & & $\begin{array}{l}\text { Sum of } \\
\text { Squares }\end{array}$ & Df & Mean Square & F & Sig \\
\hline 1 & Regression & $1249-583$ & 3 & 416,528 & 85,051 &, $00(\mathrm{a})$ \\
& Residual Total & 861,945 & 176 & 4,897 & & \\
& & 2111,528 & 179 & & & \\
\hline
\end{tabular}

According to Maydasari (2016), the Anova test shows the magnitude of the probability/significance number (sig) in the Anova calculation that will be used for the feasibility test of the regression model with the provisions that a good probability number to be used as a regression model must be smaller than 0.05 . Table 7 above produces an F figure of 85,051 with a significance level (probability number) of 0,000 .

The probability value is $0,000<0.05$, so this regression model is appropriate to be used in predicting consumer perception. This means that there is an influence on the quality of packaging design, packaging design materials and packaging label innovation on consumer perception.

\section{3) Regression Coefficient}

Describe a regression equation to find out the constant numbers and test the hypothesis of the significance of the regression. 
Table 5

Regression Coefficient

\begin{tabular}{|c|c|c|c|c|c|c|}
\hline \multirow[t]{2}{*}{ Model } & & \multirow{2}{*}{$\begin{array}{l}\text { Unstandardized } \\
\text { Coefficients } \\
\text { B } \\
\end{array}$} & \multicolumn{2}{|c|}{$\begin{array}{l}\text { Standardized } \\
\text { Coefficients }\end{array}$} & \multirow[t]{2}{*}{$\mathrm{T}$} & \multirow[t]{2}{*}{ Sig } \\
\hline & & & Std. Error & Beta & & \\
\hline \multirow[t]{4}{*}{1} & (constant) & $-1,481$ & ,959 & & $-1,545$ & ,124 \\
\hline & Total design quality & 195 & ,077 & & 2,530 & ,012 \\
\hline & Total packaging design materials & 225 & 130 & 240 & 1,725 & 0,86 \\
\hline & Total packaging innovation & ,305 & 0,52 & 169 & 5,822 & 0,00 \\
\hline
\end{tabular}

The regression equation is:

$\mathrm{Y}=\mathrm{a}+\mathrm{bX} \mathrm{X}_{1}+\mathrm{bX} 2+\mathrm{bX} 3 \ldots+\mathrm{bX}$

Where:

Y : Dependent variable (consumer perception)

a : Constant value

b : Regression coefficient

$\mathrm{X}_{1} \quad$ : Design quality (independent variable)

$\mathrm{X}_{2} \quad$ : Packaging design material (independent variable)

$\mathrm{X}_{3} \quad$ : Packaging design innovation (independent variable)

If it is included in the regression equation, it will be equal to:

$Y=-1,481+0,195 X_{1}+0,225 X_{2}+0,305 X_{3}$

A constant value of $-1,481$ means that if there is a variable level of design quality, packaging design materials and packaging design innovation has decreased, then the level of consumer perception variables also decreased by $-1,481$.

The regression coefficient of X1 is 0.195 which means that if the variable level of packaging design quality increases, the level of consumer perception variable also increases by 0.195 . The regression coefficient of X2 is 0.225 which means that if the variable level of packaging design materials increases, the level of consumer perception variables also increases. The X3 regression coefficient is 0.305 which means that if the level of label innovation variables in packaging design increases, the level of consumer perception variables also increases by 0.305 .

4) T-test

The first $t$-test will be used to test the significance of the constants and the variable quality of packaging design, which are as follows:

- Hypothesis

Ho $=$ The regression coefficient is not significant

$\mathrm{H} 1=$ The regression coefficient is significant

- Conclusion :

If $t$ count $<t$ table, then the following conditions are used:

$\alpha \quad=0.05$

$\mathrm{DF}=($ the amount of data -2$)=180-2=178$

t table $=1.653$

Because $t$ count (2.530) $>t$ table (1.653), Ho is rejected, which means the regression coefficient for the variable of design quality is significant.

The second t-test will be used to test the significance of the constants and variables of packaging design materials, which are as follows:

- Hypothesis

Ho $=$ The regression coefficient is not significant

Mahyuni, A. A. S., Sucipta, I. N., Adnyana, I. M., \& Mahendra, M. S. (2019). The consumer perception on balinese local culture-based packaging design on white oyster mushroom chips (Pleorotus ostreatus). International Journal of Life Sciences, 3(3), 41-52. https://doi.org/10.29332/ijls.v3n3.370 
H1 = The regression coefficient is significant

- Conclusion:

If $t$ count $<\mathrm{t}$ table, then the following conditions are used:

$\alpha=0.05$

$\mathrm{DF}=($ the amount of data -2$)=180-2=178$

$\mathrm{t}$ table $=1.653$

Because $t$ count (1.725) > t table (1.653), Ho is rejected, which means the regression coefficient for the variable of packaging design material is significant.

The third t-test will be used to test the significance of the constant and label innovation variables on packaging design, which are as follows:

- Hypothesis

Ho $=$ The regression coefficient is not significant

$\mathrm{H} 1$ = The regression coefficient is significant

- Conclusion :

If $t$ count $<\mathrm{t}$ table, then the following conditions are used:

$\alpha \quad=0.05$

$\mathrm{DF}=($ the amount of data -2$)=180-2=178$

$\mathrm{t}$ table $=1.653$

Because t-count (5.822) > t table (1.653), Ho is rejected, which means the regression coefficient for label innovation variables in packaging design is significant.

\section{Conclusion}

a) Local cultural identities applied to the packaging of white oyster mushroom (Pleorotus Ostreatus) chips include poleng motif, patra punggel, Barong Ket illustration, Meru Tumpang Solas illustration, and Payas Bali illustration.

b) The poleng Rwabhineda motif on the design of white oyster mushroom (Pleorotus Ostreatus) chips packaging contains a philosophical meaning that indicates the values of rwabhinedha namely the concept of difference created by Ida Sang Hyang Widhi Wasa to create harmony and balance of the universe, whereas the poleng anyar motif in the packaging design contains meaning permeation of the function of the three colors of poleng that precede it. Poleng anyar motif is a motif that uses the same patterns as the previous poleng motif, but uses a variety of color combinations. Meanwhile, the patra punggel on the packaging design is a type of patra that has an identity as an authentic Balinese patra.

c) Based on a statistical analysis of the influence of packaging design on consumer perceptions assessed positively and significantly. The influence of design quality, packaging design materials and packaging innovation on consumer perception is found in the F count test of 85.051 and the probability value is 0.000 $<0.05$ where 0.05 is the real level of the ANOVA test.

\section{Acknowledgments}

The authors would like to thank the reviewer for their consideration of the further process of the present paper. Thanks to the editor of IJLS for the valuable support, time as well as advice. 
References

Ariani, R. P., Darmawan, D. P., Atmaja, N. B., \& Wijaya, I. M. A. S. (2018). Balinese traditional culinary promotes food skills and its positive impact on tourism vocational school. International Journal of Life Sciences, 2(1), 50-62. https://doi.org/10.29332/ijls.v2n1.107

Jaminyasa, I. M., Pulawan, I. M., Martadiani, A. M., \& Amerta, I. M. S. (2017). The marketing mix affect on the consumer buying decision (case study of sausage products at PT. Aroma Denpasar). International Journal of Social Sciences and Humanities, 1(2), 65-74. https://doi.org/10.29332/ijssh.v1n2.44

Kementerian Koperasi dan UKM. 2016. Perkembangan Data Usaha Mikro, Kecil, Menengah (UMKM) dan Usaha Besar (UB) Tahun 2012 - 2013. Jakarta: Kementerian Koperasi dan UKM.

Klimchuk, M. R., \& Krasovec, S. A. (2007). Desain Kemasan: Perencanaan Merek Produk yang Berhasil Mulai dari Konsep sampai Penjualan. Penerbit Erlangga.

Korry, P. D. P., Yulianti, N. M. D. R., \& Yunita, P. I. (2017). Increase the attractiveness of local fruits to buying intention of hedonic consumers in bali. International Research Journal of Management, IT and Social Sciences, 4(6), 10-16.

Maydasari, E. (2016). The analyses of factors influencing farmer motivation at cacao farming in North Lombok. International Research Journal of Engineering, IT \& Scientific Research, 2(9), 18-25.

Rupawan, I. K. (2008). Saput poleng dalam kehidupan beragama Hindu di Bali. Pustaka Bali Post.

Suarta, I. M. (2017). Revitalization of Oral Literature Tradition of Balinese Society Based Character Values As Deradicalism Effort. International Journal of Social Sciences and Humanities, 1 (3). pp. 8-16. ISSN 25507001

Sucipta, I. N., Suriasih, K. (2016). Pengemasan Pangan (Kajian Pengemasan yang Aman, Nyaman, Efektif dan Efisien). Denpasar : Udayana University Press.

Suryasa, W. (2019). Packaging design for banten. International Research Journal of Management, IT and Social Sciences, 6(1), 70-77. https://doi.org/10.21744/irjmis.v6n1.584

Tjiptono, F., \& Pemasaran, S. (2007). Edisi Pertama. Cetakan Pertama. Yogyakarta: Andi.

Zoest, A. V. (1993). Semiotika: tentang tanda, cara kerjanya dan apa yang kita lakukan dengannya. Jakarta: Yayasan Sumber Agung.

Mahyuni, A. A. S., Sucipta, I. N., Adnyana, I. M., \& Mahendra, M. S. (2019). The consumer perception on balinese local culture-based packaging design on white oyster mushroom chips (Pleorotus ostreatus). International Journal of Life Sciences, 3(3), 41-52. https://doi.org/10.29332/ijls.v3n3.370 


\section{Biography of Authors}

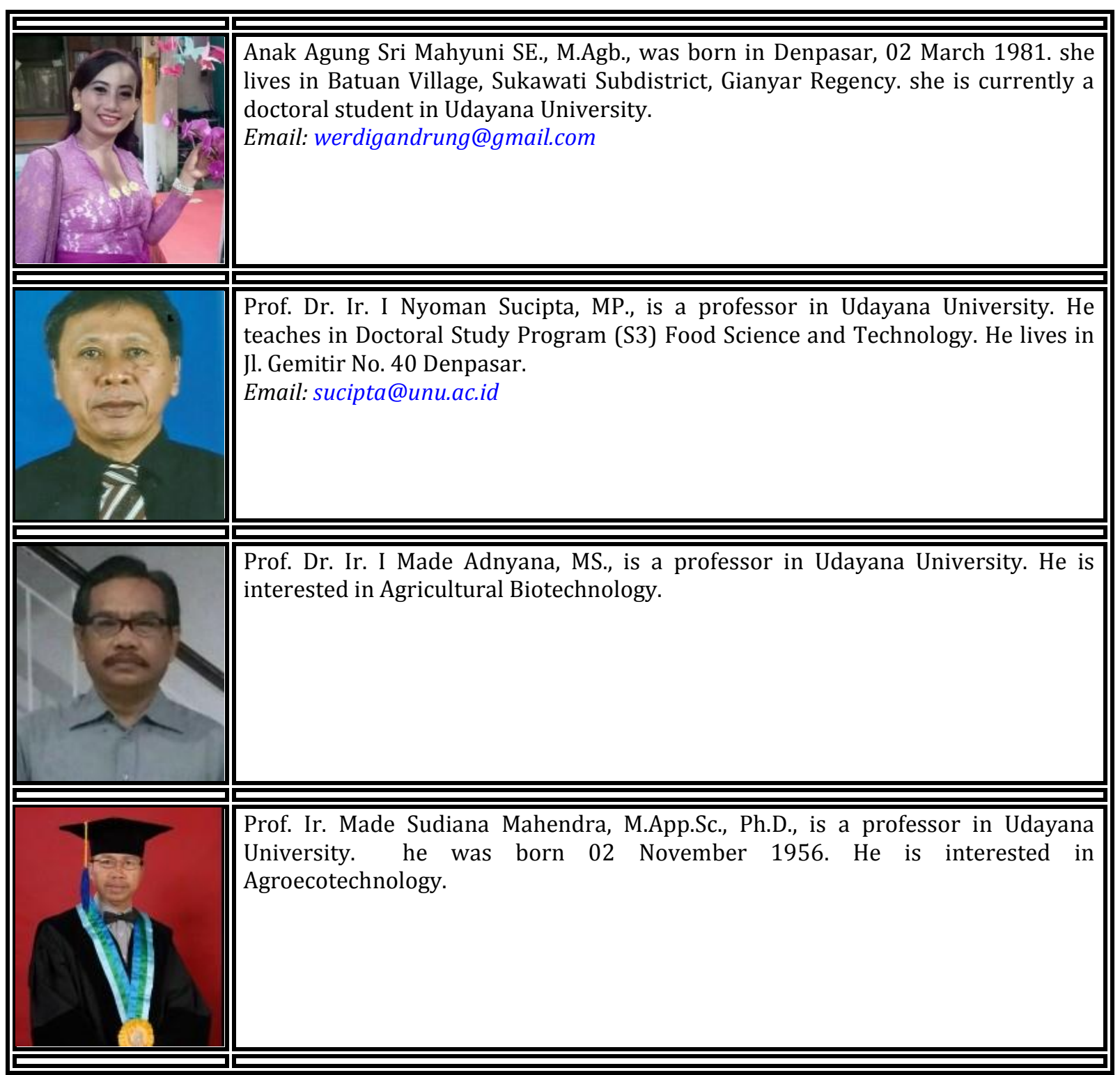

